\title{
The Visions of Lithuanian Musical Education
}

\author{
Vita Gruodytè \\ Litovska akademija za glasbo in gledališče \\ Lithuanian Academy of Music and Theatre
}

For the countries that occupied it, Lithuania was considered either as the Far East (by Germany) or as the Far West (by Russia). This particular geographical situation very precisely defines the problem that the Lithuanians faced in 1918, after the proclamation of their independence. This swaying between East and West, not only geographically, but also culturally, considerably complicated the question of national identity, which was at the same time urgently needed to be defined. According to historian Tomas Balkelis, "during the post-war conflicts, the Lithuanian identity was created in opposition to various 'enemies of the state' - Poles, Bolsheviks, Germans." In other words, the construction of identity had to begin with rejection.

\section{Beginnings of a musical awareness}

The cultural rise of the Lithuanians began at the very end of the 19th century. In his article About Music (in 1910), the first professional composer Mikalojus Konstantinas Čiurlionis (1875-1911) prefigured the future paths of Lithuanian music. He also mentioned the rejection of foreign influences, namely Polish and German music. As in Central Europe and Russia, Lithuanian musical nationalism was above all "a weapon against the supremacy of foreign musical culture."

1 Tomas Balkelis, Lemtingi metai [The Crucial Years] (Vilnius: Tyto Alba, 2019), 19.

2 Bojan Bujic, "Nationalismes et traditions nationales," in Musiques-1. Musiques du XXe siècle, ed. Jean-Jacques Nattiez (Paris: Actes Sud, 2003), 176. 
In his article, Čiurlionis aptly summarized the situation of the time:

Scandinavian, Russian and Polish music [...] began to develop in the second half of the 19th century. Lithuanian music, it can be said boldly, has a future in itself, but it is not yet the case today. We stayed away from everything. [...] Our culture is just starting to 'want to be'. We slept for a long time, under political conditions, and today, at the time of rebirth, our own laziness prevents us from working effectively. We are exhausted in a mixture of all kinds of work, and to those who want to act, the prevailing mistrust often clips their wings. ${ }^{3}$

Secondly, Čiurlionis tried to name the essential features of Lithuanian music: "The most important features of Nordic music are sadness, nostalgia, melancholy, simple and serious rhythm."

Thirdly, the composer has answered, almost prophetically, many problematic questions, which would be constantly addressed later, throughout the twentieth century. The main one was the fear of losing one's national identity in the face of external influences.

The music of each nation, while developing and growing, does not lose its individual characteristics because it is produced by composers who, as sons of their homeland, receive from their parents by blood the love of their songs and often, without realizing it, love their character and peculiarities.

The composer also named the most important music source for contemporary creation, namely the traditional songs:

Remembering that we have our old songs, we must not cease hoping. And the time will come when our composers will open this enchanted kingdom and, by drawing from this treasure their inspirations, will find in their hearts strings that have not been touched for a long time, then we will understand each other better, because this will be the true music of the Lithuanian nation. Will it happen soon? In one hundred, two or even three hundred years, if we do not 
stop, and if we succeed in engendering in society the aspirations for better music. ${ }^{6}$

The last statement corresponds particularly to the main considerations of the time, according to which,

a national musical language had to be based on the inflections of 'authentic' popular music. The folk song thus acquires the status of a sacred national treasure, supposed to ensure the connection with the distant past and to reflect the aspirations and the very soul of the nation.?

\section{Setting priorities for musical education}

Thus, in 1918, when Lithuania became free, it already had this general cultural ideological background, namely, entrenched ethnic nationalism, which could serve as a basis for the conception of public musical education. It had to replace a long tradition of private music schools, with varying levels, funded by the local nobility who, in addition, often financed the studies of their best students abroad.

The initiator of professional music education was composer Juozas Naujalis (1869-1934). He developed the teaching programme in 1917, and implemented it in 1919. The conception of the first music school, founded in Kaunas, the capital of the time, and which later (in 1933) became the State Conservatory, depended on several factors:

- Identified needs and priorities,

- State aid (financing, premises, status),

- The personal vision of the successive directors.

Music education was founded mainly by Lithuanian composers who completed their studies abroad. The geography was already great - from St. Petersburg and Warsaw to Leipzig, Berlin, Paris and Prague. Those who returned from St. Petersburg had fled the Russian Revolution; those who returned from Western Europe and the United States were rather sensitive to the ideas of national movement in their finally liberated country.

It is therefore the composers who best identified the need for Lithuanian music, because they also had a utilitarian approach: musical creation had a need for local performers. Composer Kazimieras Viktoras Banaitis

6 Ibid., 298.

7 Bujic, "Nationalismes et traditions nationales," 176. 
(1896-1963) (who had taught at the Kaunas School of Music since 1928 and became director of the Conservatory in 1937), wrote in 1919:

For some, it may seem that we [...] lack more vocational schools such as technical, agricultural, or midwives' schools, etc. In fact, it's just the opposite. [...] In addition to the purely specialized vocational schools, meeting the material needs of life, there is also a great need for many institutions of spiritual culture, such as music, arts, drama and other schools. This need is felt even by small enslaved nations, so what can be said about free nations or those that have restored political freedom, among which we can count ourselves. After proclaiming the independence of Lithuania, we will need various national concerts, parties, anniversaries, festivities which, without music and singing, would be like a boring recitation, a stiff body without spirit or soul. The School of Music will prepare for this purpose the appropriate musical and artistic forces, whose absence has been felt so far. ${ }^{8}$

In addition to the pragmatic approach, Banaitis saw the development of music education at the national level as an important social aspect. For example, he wanted Lithuanian talents to remain in their country because talented students did not always have financial opportunities. It was also important for him that organists, established in the provinces, raise their own musical culture and the general level of ecclesiastic music. Moreover, the future music institutions would accelerate the collection and transcription of authentic popular music, threatened with disappearance and oblivion. Because, according to the composer,

It would be desirable that should be explained the peculiarities of our folk music, of aesthetic, theoretical advantages and value of Lithuanian popular melodies, and their relationship with the musical features of neighboring nations.'

One of the main priorities of the time was the creation of the National Opera Theatre (founded in 1922), which housed opera and drama troupes. The need for soloists and opera musicians was pressing, since the first Lithuanian opera (Birute by Mikas Petrauskas) had been created as early as 129.

9 Narbutienè, Kazimieras Viktoras Banaitis, 134. 
1906 with extremely poor artistic means. As a result, the Opera was the most relevant and, in fact, the best-funded cultural institution.

In 1936, barely three years after the Kaunas School of Music acquired the status of Conservatory, the composer and its long-time director, Juozas Gruodis (1884-1948), emphasized the effectiveness of music education:

The Kaunas Conservatory gave musicians mainly for the National Opera. There are more than 40 soloists in the orchestra and choir, [...] as well as 23 students of the conservatory in the State Radio Orchestra. $^{\text {. }}$

The director of Klaipeda Music School, composer Stasys Šimkus, was very excited about preparing musicians for a professional symphony orchestra. It was the first specialization of this school and the first difference with its rival, the Kaunas Music School, because at the beginning of the educational activity, both institutions were very similar. In 1924, Šimkus's initiative received financial support from the Minister of National Education. ${ }^{\text {II }}$ It is obvious that the aim of the professional orchestras was to encourage the creation of symphonic works by Lithuanian composers. The First Lithuanian symphony, written by Juozas Žilevičius in 1919, was created in Kaunas in 1923 by a private orchestra.

The musical education of organists was another priority. They were the main actors of the provinces, due to their being performers, composers and teachers. Thanks to the strong influence of Caecilian Movement in the church music, Gregorian chant replaced the pseudo-romantic, and therefore pseudo-sacred, style of Polish music.

Various foreign teaching traditions, upon which it was necessary to count before being completely autonomous, created in Lithuania a rich and high-level environment. For example, the piano was taught according to the principles of the conservatories of Riga, Leipzig and St. Petersburg; singing, according to the principles of the Italian and French schools; the violin, according to the German and Russian schools; and the wind instruments, according to the German school, dominant at the time. Visiting professors gradually gave way to local graduates, although foreign schools

10 Algirdas Jonas Ambrazas, ed., Juozas Gruodis, Straipsniai, laiškai, užrašai. Amžininku atsiminimai [Articles, letters, notes. Memories of contemporaries] (Vilnius: Vaga, 1965), 233-234.

11 Danute Petrauskaitė, Klaipédos muzikos mokykla 1923-1939 [Klaipeda School of Music in 1923-1939] (Klaipèda: Mažosios Lietuvos fondas, 1998), 26-27. 
remained present throughout the inter-war period. The most significant of those were Hungarian and Czech professors, who had settled in Klaipeda. ${ }^{\text {I2 }}$

At that time, Lithuanian musicology corresponded to European tendencies, that is, it was focused on theoretical textbooks, biographies, and music criticism.

Of course, music education was primarily devoted to the training of composers. The first class of composition was opened in 1927 by Juozas Gruodis, who was the first and for a long time the only teacher of composition. His role in training a whole lineage of composers was very important, and has been highlighted in many recent studies.

\section{Tensions between traditionalist, moderate and modernist composers}

The main ideological conflict was between so-called traditionalist, modernist and moderate composers. The older generation studied rather in Warsaw or St. Petersburg, while young musicians studied in Berlin, Leipzig, Prague or Paris. The differences lay not so much in age as in their relationship to musical modernity. The two main music schools of Lithuania were founded by traditionalists (Juozas Naujalis in Kaunas, Stasys Šimkus in Klaipeda). Juozas Naujalis studied in Warsaw with Zygmunt Noskowski (Karol Szymanowski's teacher) who was reluctant to deal with new musical styles such as the impressionism of Debussy or Ravel.

"Young people consider me [...] a backlog [...] because I'm not a modernist, but a classical composer," Naujalis complained.

He understood the importance of the national musical style, but he could not solve these problems himself. His music was dominated by Polish influences, and he did not know enough Lithuanian folklore. He simply did not have the technical means to participate in the creation of a Lithuanian musical identity. The national schools were founded during the national revival and the blossoming of the identity awareness, so that the lack of this consciousness was the biggest obstacle, not only to modernity, but simply to the participation in the musical discourse and the musical language of the time.

12 Danutè Petrauskaite, "Klaipèdos muzikos mokykla" [Klaipeda School of Music], in Lietuvos muzikos istorija II: Nepriklausomybès metai 1918-1940, ed. A. J. Ambrazas (Vinius: Lietuvos muzikos akademija, 2009), 258. 
In 1927 Naujalis was replaced by a moderate Juozas Gruodis. Some composers, though modern while studying abroad, became very moderate when they returned home. They were influenced or rather crushed by the very conservative public and context. This is the case of Vladas Jakubenas, returned to Kaunas in 1932, a teacher at the Conservatoire and a very active music critic. His works written in Berlin (Prelude and First Symphony) shocked local musicians. He quickly lost confidence in new Western music, turned away from atonality, and contented himself with the use of folk music in a fairly classical tonal system.

In the 1930s, the return of several modernist composers from abroad changed the game. This generation was very actively involved in the educational process, but not without problems. Opposing artistic visions, strong characters and even competition between the two schools of Kaunas and Klaipeda, created tensions.

Therefore, it was difficult not only for traditionalists like Naujalis, but also for modernists. For example, one of them, Jeronimas Kačinskas, after returning from Prague where he studied with Alois Haba, tried to promote the microtonal language, but did not receive support. Gruodis did not support him either. Then Kačinskas left the capital, moved to Klaipeda and opened a quarter-tone composition class (since 1933). Another modernist, Vytautas Bacevičius, who taught at Kaunas (from 1930 to 1938), could not realize his visions of contemporary music either, extremely modern for the time. According to Ona Narbutienè,

Romanticism was totally alien to the composer; therefore, his music seemed unacceptable to the majority of listeners. They missed the coherent musical flow and the wrought-out melody that guides a certain musical thought. ${ }^{14}$

Juozas Gruodis, his director at the conservatory, said of Bacevičius:

It's not normal for a very talented creator to create for himself, for future generations, instead of trying to lead his people with him, a people to whom he shows his contempt. The artist must not descend into the crowd, but he must be able to the crowd for which he writes his works. ${ }^{\mathrm{Is}}$

14 Vita Gruodyte, "Vytautas Bacevičius in the Context of Interwar Paris," in Vytautas Bacevičius in Context, eds. Rūta Stanevičiūtè and Veronika Janatjeva (Vilnius: Lithuanian Composers' Union, 2009), 50. 
The musical field was constructed as a permanent search for balance between opposing ideas and visions. The prevailing conservatism has led many people to settle for a certain consensus. This is why a composer like Gruodis was able to establish himself as a rallying force.

The boundaries between traditionalist, moderate and modernist composers were blurred through a general policy of a basic and solid education, even though the influence of younger colleagues on the general atmosphere was increasingly making itself felt.

While the first decade after independence in 1918 was dedicated to the institutional development of the education system, the second decade brought new ideas. Despite a rather hostile atmosphere, Kačinskas and Bacevičius founded The Society of Progressist Musicians (1932) in order to promote contemporary music.

Their vision of modern music was closer to the Western musical avant-garde than to neo-folklorism popular in Lithuanian music of the time... ${ }^{16}$

Thanks to them, Lithuania joined the International Society for Contemporary Music (ISCM) in 1936, and Kačinskas' Nonet was even played in 1938 during the ISCM days in London.

It is only from this second decade that we can start talking about the "normal" development of a musical life in a free country, which, unfortunately, was brutally interrupted by the Second World War, and by a new occupation, this time Soviet.

\section{From collective needs to individual visions}

It is natural that the initial idea of music education, which was to join collective forces to meet the needs of a young state, gradually gave way to individual ambitions and personal visions.

Jeronimas Kačinskas said:

The concept of nationality must be taken in a broad sense. Lithuanian specificity cannot be linked only to the structure and spirit of old folk songs. Why, by looking for the Lithuanian character in old songs, in Lithuanian nature, its forests, rivers and lakes, why does one bypass the most important source of identity, namely one's own

16 Rūta Stanevičiūte, "Introduction," in Vytautas Bacevičius in Context, eds. Rūta StanevičiūtėandVeronikaJanatjeva(Vilnius:LithuanianComposers'Union, 2009), 10. 
individuality? Is it possible that a free creator can be foreign to the spirit of his country? It is difficult to determine where the national peculiarities of our music begin and end. Because each person is a different individual, the artistic paths of the creators of a nation are thus very different. Restricting the artist by the so-called common laws of national music would deprive him of his ultimate creative factor, of his individuality. If the creator does not follow his inner inspirations, but seeks mechanical correspondences with popular music, with his environment, he will not be able to translate substantially the characteristics of the Lithuanian soul..$^{17}$

These words marvelously connect, but with more maturity, the ideas of M. K. Čiurlionis, cited above.

Vytautas Bacevičius was even more radical, strongly influenced by Alexander Scriabin, Edgard Varèse, André Jolivet and marked by 'universal thought'. He said: "I developed fully the concept of cosmic music;";8

I wanted to capture those elements of life that characterise the spirit of our zoth century [...]. Machinism should be considered here not only as an outward phenomenon of our life but as its inner element; ${ }^{19}$

For Bacevičius,

original creativity could bow to no external pressure (the tastes of the audience, the demands of the market, the limitations imposed by commissions); the freedom of the artist consisted in his sovereignty and manifested itself in his independence in bringing to life his own vision. ${ }^{20}$

He said: "I can't imagine composing without my own satisfaction."

17 Ona Narbutienè, Muzikinis Kaunas 1920-1940 [Musical Kaunas in 1920-1940] (Kaunas: Šviesa, 1992), 74.

18 Ona Narbutienė, "The Fate and Spread of Vytautas Bacevičius's Artistic Vision," in Vytautas Bacevičius in Context, eds. Rūta Stanevičiūtė and Veronika Janatjeva (Vilnius: Lithuanian Composers' Union, 2009), 29.

19 Ibid., 25.

20 Ibid., 121-122.

21 Krzysztof Droba, "Vytautas Bacevičius in Amerika, or an Artist in the Cage," in Vytautas Bacevičius in Context, eds. Rūta Stanevičiūtè, Veronika Janatjeva (Vilnius: Lithuanian Composers' Union, 2009), 122. 
Nevertheless, later Bacevičius

opted for the music that would combine the atonal language with the elements of tradition, an approach he himself described as 'synthetic style..22

The transition from the classical teaching tradition to the learning of modern musical languages, the change of mentalities, ranging from collective policies to the realization of individual visions, was the main achievement of the young Republic of Lithuania. The national conception of music was born from the constant awareness of its own traditions, the needs of its own culture, and the advances of Western music. If at the beginning of independence, the latter were rejected for identity reasons, they were again accepted towards the end of this short period, and partly adopted. It was a sign of intellectual and cultural maturity. The paradigm conflict between ethnicity (i.e. country culture) and modernity (i.e. urban culture) in Lithuania was no exception. It was felt in many countries of Central and Eastern Europe. Unfortunately, the new occupation scared away the best musicians: opera soloists, instrumentalists, pedagogues and the most innovative composers.

The Soviet regime, as we know, has not only banned composers from the use of modern musical languages, but also banned ecclesiastic music. Despite this, the achievements of the first half of the $20^{\text {th }}$ century have not been forgotten by Lithuanians. They were considered both as a loss and a hope. It is therefore quite natural for those two aspects of musical life to become again a priority in the reconquest of the new Lithuanian independence in $1990,{ }^{23}$ and of its new musical identity. But, like at the beginning of the twentieth century, it was necessary once again to solve financial and institutional problems.

\section{Bibliography}

Ambrazas, Algirdas Jonas, ed. Juozas Gruodis, Straipsniai, laiškai, užrašai. Amžininku atsiminimai [Articles, letters, notes. Memories of contemporaries]. Vilnius: Vaga, 1965.

Balkelis, Tomas. Lemtingi metai [The Crucial Years]. Vilnius: Tyto Alba, 2019.

\section{Ibid.}

23 Viktoras Gerulaitis, "Pirmieji savarankiškos Lietuvos kompozitorių sąjungos metai" [The first years of the Union of Composers of Independent Lithuania], Muzika, no. 9-10 (1990): 5-10. 
Bujic, Bojan. „Nationalismes et traditions nationales.“ In Musiques-1. Musiques du XXe siècle, edited by Jean-Jacques Nattiez, 175-194. Paris: Actes Sud, 2003.

Čiurlionis, Mikalojus Konstantinas. Apie muzika ir daile [About music and art]. Vilnius: Valstybinè grožinès literatūros leidykla, 1960.

Droba, Krzysztof. "Vytautas Bacevičius in Amerika, or an Artist in the Cage." In Vytautas Bacevičius in Context, edited by Rūta Stanevičiūtè and Veronika Janatjeva, 119-134. Vilnius: Lithuanian Composers' Union, 2009.

Gerulaitis, Viktoras."Pirmieji savarankiškos Lietuvos kompozitorių sąjungos metai" [The first years of the Union of Composers of Independent Lithuania]. Muzika no. 9-10 (1990): 5-10.

Gruodyte, Vita. "Vytautas Bacevičius in the Context of Interwar Paris." In Vytautas Bacevičius in Context, edited by Rūta Stanevičiūtė and Veronika Janatjeva, 49-69. Vilnius: Lithuanian Composers' Union, 2009.

Narbutienè, Ona. Juozas Naujalis. Kaunas: Šviesa, 1989.

Narbutienè, Ona. Muzikinis Kaunas 1920-1940 [Musical Kaunas in 1920-1940]. Kaunas: Šviesa, 1992.

Narbutienè, Ona. Kazimieras Viktoras Banaitis. Vilnius: Baltos lankos, 1996.

Narbutienè, Ona. “The Fate and Spread of Vytautas Bacevičius's Artistic Vision.” In Vytautas Bacevičius in Context, edited by Rūta Stanevičiūtė and Veronika Janatjeva, 21-30. Vilnius: Lithuanian Composers' Union, 2009.

Petrauskaitè, Danutè. Klaipédos muzikos mokykla 1923-1939 [Klaipeda School of Music in 1923-1939]. Klaipèda: Mažosios Lietuvos fondas, 1998.

Petrauskaitè, Danutè. "Klaipėdos muzikos mokykla” [Klaipeda School of Music]. In Lietuvos muzikos istorija II: Nepriklausomybes metai 1918-1940, edited by A. J. Ambrazas, 255-267. Vilnius: Lietuvos muzikos akademija, 2009.

Stanevičiūtè, Rūta. "Introduction.” In Vytautas Bacevičius in Context, edited by Rūta Stanevičiūtè and Veronika Janatjeva, 9-17. Vilnius: Lithuanian Composers' Union, 2009. 